\title{
Tissue composition and allometric growth of tissues from commercial cuts and carcass of Texel lambs slaughtered with different weights
}

\section{Composição tecidual e crescimento alométrico dos tecidos dos cortes comerciais e da carcaça de cordeiros da raça Texel abatidos com diferentes pesos}

\author{
Sérgio Carvalho ${ }^{1 *}$; Luana Cortes Zago ${ }^{2}$; Cleber Cassol Pires ${ }^{3}$; \\ Andressa Ana Martins'; ${ }^{2}$ Rafael Sanches Venturini²; Jusecléia Ferreira Lopes ${ }^{2}$; \\ Verônica Milanesi Pilleco²; Robson Rodrigues Simões²; \\ Daniele Dias Bruti'; Anderson Bortoluzi Moro
}

\begin{abstract}
In this study, we evaluated the tissue composition, the ratios between different issues, and the allometric growth of tissues from the commercial cuts neck, shoulder, rib, and leg, and of the carcass of Texel lambs. Thirty uncastrated male lambs born from single calvings were used in this experiment. Lambs were weaned, confined individually, and distributed into five treatments with six replications. Each treatment consisted of a predefined slaughter weight (T23 - initial slaughter, T25, T30, T35, and T40). The proportion of bone decreased linearly in the shoulder, rib, and legs, but remained constant in the neck. The proportion of muscle decreased in the rib, whereas in the other cuts it remained constant. The percentage of fat increased as the slaughter weight of the lambs was increased, for all cuts. In all cuts and in the carcass, bone and muscle showed early growth $(b<1)$, whereas fat displayed late growth $(\mathrm{b}>1)$. The proportion of bone decreased and fat increased linearly in the carcass, and the proportion of muscle was not influenced by the slaughter weight of the lambs. The muscle/fat ratio decreased in all cuts, and consequently in the half-carcass, as the slaughter weight was increased. The muscle/ bone ratio increased in the shoulder, rib, leg, and half-carcass, but there was no significant effect on the neck. The bone and muscle tissues showed early growth, whereas the fat had late growth in the different commercial cuts and carcass of Texel lambs. The tissue growth pattern of the shoulder may be representative of the allometric growth of the different carcass tissues. An increase in the slaughter weight of Texel lambs leads to a reduction of the muscle/fat ratio, due to the higher deposition of fat in the carcass of these animals.
\end{abstract}

Key words: Meat. Confinement. Fat. Muscle. Bone. Sheep.

1 Prof. Adjunto, Dept ${ }^{\circ}$ de Zootecnia, Universidade Federal de Santa Maria, UFSM, Santa Maria, RS, Brasil. E-mail: scarvalhoufsm@ hotmail.com

2 Discentes do Programa de Pós-Graduação em Zootecnia, UFSM, Santa Maria, RS, Brasil. E-mail: luanaczago@yahoo.com.br; dess.a@hotmail.com; rs_venturini@hotmail.com; jussiferreira@hotmail.com; vemilpilecco@hotmail.com; robsonrsimoes@ hotmail.com; andersondazoo@hotmail.com

3 Prof. Titular, Dept ${ }^{\circ}$ de Zootecnia, UFSM, Santa Maria, RS, Brasil. E-mail: pirescleber@hotmail.com

4 Discente do Curso de Graduação em Zootecnia, UFSM, Santa Maria, RS, Brasil. E-mail: dani_brutti@hotmail.com

Author for correspondence 


\section{Resumo}

Avaliou-se a composição tecidual, a relação existente entre os diferentes tecidos e o crescimento alométrico dos tecidos dos cortes comerciais pescoço, paleta, costilhar e perna e da carcaça de cordeiros da raça Texel. Foram utilizados 30 cordeiros machos, não castrados e nascidos de parto simples. Os cordeiros foram desmamados, confinados individualmente e distribuídos em cinco tratamentos com seis repetições, sendo cada tratamento um peso pré-estabelecido de abate (T23 - abate inicial, T25, T30, T35 e T40). A proporção de osso diminuiu linearmente na paleta, no costilhar e na perna e se manteve constante no pescoço. A proporção de músculo diminuiu apenas no costilhar, enquanto que nos demais cortes se manteve constante. A porcentagem de gordura aumentou com a elevação do peso de abate dos cordeiros, em todos os cortes realizados. Em todos os cortes e na carcaça, o osso e o músculo apresentaram crescimento precoce $(b<1)$, enquanto que a gordura apresentou crescimento tardio $(b>1)$. A proporção de osso diminuiu e a de gordura aumentou linearmente na carcaça, enquanto que a proporção de músculo não foi influenciada pelo peso de abate dos cordeiros. A relação músculo/gordura diminuiu em todos os cortes e, consequentemente, na meia carcaça com o aumento no peso de abate dos cordeiros. Já a relação músculo/osso aumentou na paleta, no costilhar, na perna e na meia carcaça, e não houve efeito significativo no pescoço. Os tecidos ósseo e muscular apresentam crescimento precoce, enquanto que a gordura apresenta crescimento tardio nos diferentes cortes comerciais e na carcaça de cordeiros da raça Texel. O padrão de crescimento tecidual da paleta pode ser representativo do crescimento alométrico dos diferentes tecidos da carcaça. O aumento do peso de abate de cordeiros da raça Texel leva à diminuição da relação músculo/gordura como consequência da maior deposição de gordura na carcaça dos animais.

Palavras-chave: Carne. Confinamento. Gordura. Músculo. Osso. Ovino.

\section{Introduction}

There are many factors determining the quality of a carcass and its cuts; however, it is known that the consumer has a preference for products with the right amount of fat and good meat yield. For this reason, younger animals must be produced. This type of animal/category can be obtained in a large scale if investments are made in technology, as is the case of lamb finishing held in the feedlot, a technique adopted to maximize production and also produce carcasses according to the demand of the consumer market.

According to Sañudo and Sierra (1993), despite the complexity of tissues that form it, in practice, the carcass tissue composition corresponds to the amounts of fat, muscle, and bone, which vary according to many factors, among which are the age, genetic basis, management system, and feeding. Full dissection of the carcass for measuring the amount of these three tissues is the most accurate method for its evaluation.
The use of breeds specialized for meat production - pure or resulting from crossbreeding -is an important instrument in the search for quality sheep meat (CARVALHO et al., 2005). Oliveira et al. (1998) studied the meat production of sheep of five genotypes and emphasized that Texel lambs showed a lower percentage of bone in the leg and shoulder and a higher percentage of muscle compared with the Romney Marsh, Corriedale, Ideal, and Merino breeds. Therefore, the breed aspect is clearly decisive in the tissue composition of commercial cuts that make up the sheep carcass.

In addition to the evaluation of amount and proportion of tissues, another study is necessary: the relative development of each one of them in relation to body growth and of each carcass region. According to Black (1983), tissues that increase in weight at a higher rate than body weight, in the post-natal period, are classified as early, and tissues with the opposite characteristic are considered late. 
An increase in body weight can determine alterations in the carcass characteristics and traits of commercial interest. As an example, the muscle/ bone and muscle/fat ratios are altered, with the former increasing along with the slaughter weight, and the second decreasing.

This study aimed to evaluate the tissue composition and the ratios between tissues, in addition to investigating their allometric growth in relation to the cuts made in the carcass of Texel lambs slaughtered with different weights.

\section{Materials and Methods}

The experiment was conducted in the Sheep Farming Laboratory at the Department of Animal Science as part of the Graduate Program in Animal Science of the Federal University of Santa Maria (UFSM), located in Santa Maria, RS, Brazil, in the period between September and December 2011. Thirty uncastrated male lambs of the Texel breed, born from single calvings, were used in the experiment. The animals were confined in fully covered individual stalls with slatted floor, approximately $1.0 \mathrm{~m}$ above the soil, with $2 \mathrm{~m}^{2}$ per animal.
A completely randomized experimental design with five treatments and six replications was adopted. Treatments consisted of different predefined slaughter weights, except for the first, in which case the weight represented the average calculated as the sum of live weight of the six lambs on the slaughter day performed on the last day of the pre-experimental period. Accordingly, the following treatments were tested: T23 $-23.4 \mathrm{~kg}$ live weight (initial slaughter); T25 - $25 \mathrm{~kg}$ live weight; T30 - $30 \mathrm{~kg}$ live weight; T35 - $35 \mathrm{~kg}$ live weight; and $\mathrm{T} 40-40 \mathrm{~kg}$ live weight.

Lambs remained with their mothers, on a natural pasture, until they reached approximately 50 days of age, when they were weaned and then confined. The diet was composed of sorghum silage (Sorghum bicolor (L) Moench), ground corn (Zea mays L.), soybean meal (Glycine max L.), and a mineral mix, calculated to meet the requirements recommended by NRC (2007) for a daily weight gain of $0.250 \mathrm{~kg}$. All lambs received the same experimental diet (Table 1). Animals were fed twice daily, at the predefined times of $08 \mathrm{~h} 30$ and $16 \mathrm{~h} 30$. The amount supplied to the animals was adjusted so as to keep refusals at $10 \%$ of the total provided on the previous day.

Table 1. Proportion of ingredients ( $\% \mathrm{DM})$ and chemical composition of experimental diets.

\begin{tabular}{lc}
\hline & Proportion of ingredients (\%)M) \\
\hline Sorghum silage & 50.00 \\
Broken corn & 20.56 \\
Soybean meal & 28.42 \\
Calcitic limestone & 1.02 \\
\hline Dry matter & 55.68 \\
Organic matter & 94.65 \\
Crude protein & 18.81 \\
Ether extract & 4.20 \\
Neutral detergent fiber & 33.33 \\
Acid detergent fiber & 16.88 \\
Total carbohydrates & 72.43 \\
Non-structural carbohydrates & 33.50 \\
Ash & 5.43 \\
Total digestible nutrients & 69.73 \\
Calcium & 0.63 \\
Phosphorus & 0.31 \\
\hline
\end{tabular}


The experimental period was preceded by 14 days of acclimation to the facilities, feeding, and management conditions. The feeding trial began after the acclimation period, extending to the moment in which each lamb reached the predefined slaughter weight, according to the treatments. At the beginning of the experimental period, six lambs (T23), representing the animals that started the experimental period, were slaughtered. Animals were weighed at the beginning of the experimental period and at every interval of seven days.

Once the lambs reached the predefined slaughter weight, they were weighed for determination of live weight at slaughter. Next, the lambs were sacrificed by sectioning the carotid arteries and jugular veins. After each slaughter, carcasses were weighed individually and then chilled for $24 \mathrm{~h}$ in a cold room at a temperature of $2{ }^{\circ} \mathrm{C}$. After this period, carcasses were weighed again, and the right halfcarcasses were subjected to regional, or anatomical separation, according to Osório et al. (1998), into neck, shoulder, rib, and leg. These cuts were identified, packed, and frozen for later evaluation of tissue composition.

After thawing, the cuts were dissected with a scalpel for determining the amounts of bone, muscle, fat, and other tissues (ganglia, fascia, tendons, and great vessels). Each of the tissues that made up the cuts were weighed on an electronic scale and their proportion was calculated relative to the respective cut.

A completely randomized design with five treatments and six replications was adopted. After data collection, results were subjected to analysis of variance, and the linear, quadratic, and cubic models were tested, using the significance of the regression coefficients and the determination coefficient as criteria to identify the best model. SAS (2001) statistical package was used for the analyses.

The allometric growth of the tissue components of each cut relative to the weight of the very cut was analyzed by the non-linear model of Huxley (1932)'s exponential equation, defined as $\mathrm{Y}=\mathrm{a} \mathrm{X}^{\mathrm{b}}$, transformed logarithmically into the simple linear model $\log y=\log a+b \log x$.

To check the $b=1$ hypothesis, (Student's) t test was applied with a significance level of $5 \%$. The growth was termed isogonic when $b=1$, indicating that the survival rates of " $y$ " (tissue component) and " $x$ " (weight of the cut) were similar in the growth interval in consideration. When $b \neq 1$, the growth was considered heterogonic: early if $b<1$ and late of $b>1$.

The present study is part of a project approved by the Ethics Committee on Animal Use of the Center for Rural Sciences at the Federal University of Santa Maria (CEUA-UFSM), under case no. 006.

\section{Results and Discussion}

The proportion of bone decreased linearly in the shoulder, rib, and legs, and remained constant in the neck $(\hat{Y}=18.37 \%)$ as the live weight at slaughter (LWS) was increased (Table 2). The proportion of muscle decreased only in the rib, whereas in the other cuts it remained constant, averaging $49.85 \%$, $56.51 \%$, and $63.41 \%$ for neck, shoulder, and leg, respectively. The percentage of fat increased from 23 to $40 \mathrm{~kg}$ LWS in all cuts, indicating that the heavier the animal, the larger the proportion of fat in any of the carcass cuts. This result was expected, because as the live weight of the lambs was increased, more fat was deposited in their carcass and consequently in the evaluated commercial cuts, which also led to a higher fattening degree of these carcasses.

Comparing the results of the present study with those reported by Mendonça et al. (2008) in Texel lambs born in August, kept on an improved native field, and slaughtered at an average age of 129 days, the proportion of bone in the shoulder and leg in all treatments was lower than that obtained by these authors: $22.12 \%$ and $21.46 \%$, respectively. The percentage of muscle of these same cuts was higher (except for the leg on T40), as they found mean 
values of $49.85 \%$ in the shoulder and $58.02 \%$ in the leg. However, the percentage of fat of these two cuts in the carcasses of animals from T30 was the same in both studies. The nutritional effect on the carcass tissue composition has been widely studied, and it has been shown that animals with a better feeding regime yield carcasses of better quality, demonstrated by the greater muscle development, good fat deposition, and lower proportion of bones (DIAZ et al., 2002; SANTOS-SILVA et al., 2002).

Table 2. Mean values of the proportions (\%) of each tissue, within each carcass cut, according to the live weight of the lambs at slaughter.

\begin{tabular}{|c|c|c|c|c|c|c|c|c|}
\hline \multirow[b]{2}{*}{ Variable } & \multicolumn{5}{|c|}{ Treatment } & \multirow[b]{2}{*}{$\mathbf{R E}$} & \multirow[b]{2}{*}{ CV (\%) } & \multirow[b]{2}{*}{$\mathbf{P}>\mathbf{F}$} \\
\hline & 23 & 25 & 30 & 35 & 40 & & & \\
\hline \multicolumn{9}{|l|}{ Neck } \\
\hline Bone & 20.93 & 20.09 & 17.16 & 19.31 & 16.52 & $\bar{Y}=18.37$ & 16.60 & 0.1626 \\
\hline Muscle & 55.10 & 53.42 & 47.46 & 48.72 & 49.94 & $\bar{Y}=49.85$ & 11.09 & 0.1235 \\
\hline Fat & 17.69 & 19.29 & 25.52 & 23.94 & 27.72 & 1 & 16.75 & 0.0054 \\
\hline Others & 6.28 & 7.19 & 9.85 & 8.03 & 5.81 & 2 & 37.63 & 0.0504 \\
\hline \multicolumn{9}{|l|}{ Shoulder } \\
\hline Bone & 19.25 & 20.67 & 18.10 & 16.32 & 15.93 & 3 & 9.58 & 0.0001 \\
\hline Muscle & 60.53 & 58.10 & 56.30 & 56.24 & 54.71 & $\bar{Y}=56.51$ & 6.36 & 0.1374 \\
\hline Fat & 15.50 & 15.60 & 18.61 & 19.88 & 23.32 & 4 & 19.32 & 0.0027 \\
\hline Others & 4.72 & 5.62 & 7.00 & 7.55 & 6.04 & 5 & 23.67 & 0.0456 \\
\hline \multicolumn{9}{|l|}{ Rib } \\
\hline Bone & 18.36 & 17.65 & 13.49 & 11.92 & 13.16 & 6 & 17.10 & 0.0026 \\
\hline Muscle & 55.14 & 53.30 & 49.50 & 50.78 & 49.35 & 7 & 6.85 & 0.0054 \\
\hline Fat & 19.12 & 21.48 & 26.70 & 27.01 & 28.72 & 8 & 17.28 & 0.0147 \\
\hline Others & 7.37 & 7.57 & 10.30 & 10.28 & 8.76 & 9 & 26.98 & 0.0420 \\
\hline \multicolumn{9}{|l|}{ Leg } \\
\hline Bone & 18.38 & 19.13 & 17.52 & 16.93 & 16.21 & 10 & 5.96 & 0.0001 \\
\hline Muscle & 65.01 & 64.03 & 63.08 & 63.06 & 63.24 & $\overline{\mathrm{Y}}=63.41$ & 3.73 & 0.5462 \\
\hline Fat & 11.58 & 11.50 & 12.63 & 13.26 & 14.95 & 11 & 15.45 & 0.0096 \\
\hline Others & 5.03 & 5.34 & 6.77 & 6.75 & 5.60 & 12 & 22.84 & 0.0449 \\
\hline
\end{tabular}

$1-\hat{Y}=8.51656+0.47821 L W S . R^{2}=0.33 ; 2-\hat{Y}=-41.94300+3.29123 L W S-0.05262 L^{2} S^{2} . R^{2}=0.22 ; 3-\hat{Y}=28.09040-$ $0.32114 \mathrm{LWS}$. $\mathrm{R}^{2}=0.55 ; 4-\hat{\mathrm{Y}}=3.55964+0.48538 \mathrm{LWS} . \mathrm{R}^{2}=0.37 ; 5-\hat{\mathrm{Y}}=-23.70882+1.87809 \mathrm{LWS}-0.02831 \mathrm{LWS}^{2} . \mathrm{R}^{2}=0.22 ;$ $6-\hat{Y}=24.26788-0.31626$ LWS. $R^{2}=37 ; 7-\hat{Y}=55.39813-0.14400 L W S . R^{2}=0.26 ; 8-\hat{Y}=11.13189+0.45459 L W S$. R $=0.26$; $9-\hat{Y}=-40.72655+3.10881 \mathrm{LWS}-0.04688 \mathrm{LWS}^{2} . \mathrm{R}^{2}=0.22 ; 10-\hat{\mathrm{Y}}=23.59815-0.18935 \mathrm{LWS} . \mathrm{R}^{2}=0.53 ; 11-\hat{\mathrm{Y}}=5.91089+$ $0.21944 \mathrm{LWS} . \mathrm{R}^{2}=0.29 ; 12-\hat{\mathrm{Y}}=-20.67009+1.68119 \mathrm{LWS}-0.02562 \mathrm{LWS}^{2} . \mathrm{R}^{2}=0.20 ; \mathrm{LWS}=$ lamb weight at slaughter.

In a comparison of the regression equations obtained by Silva and Pires (2000), who evaluated crossbred Texel lambs slaughtered with different weights, in both studies, the proportion of bone in the shoulder decreased and that of fat increased. However, while in the afore-mentioned study the proportion of muscle also increased, in the present investigation it remained constant. As regards the leg, only fat deposition was equal, increasing in both studies, because while these authors found an increase in percentage of bone and muscle, in our experiment the percentage of bone decreased and muscle remained constant.

In both cuts, the bone and muscle showed early growth $(b<1)$, while the fat showed late growth (b>1) (Table 3). However, the earliness of the bone tissue varies slightly between regions, with earlier progression in shoulder and rib than neck and leg. Silva et al. (2000) also found early growth for the 
bone tissue in all of the carcass cuts of lambs born from Texel sheep. This tissue also showed to have a faster growth in the shoulder $(b=0.64811)$ and, unlike the present study, in the leg $(b=0.53736)$ than in the other cuts (ribs $(b=0.84876)$, T-bone $(b=0.72319)$, and neck $(b=0.82294))$.

Table 3. Estimates parameters of the allometric equations of tissue components of neck, shoulder, rib, and leg, relative to the weight of each cut.

\begin{tabular}{lccccc}
\hline \multicolumn{1}{c}{ Variable } & $\mathbf{A}$ & $\mathbf{b}$ & $\mathbf{S b}$ & $\begin{array}{c}\text { T test } \\
\text { Ho: } \mathbf{b}=\mathbf{1}\end{array}$ & $\mathbf{R}^{\mathbf{2}}$ \\
\hline Neck & & & & & \\
Bone & -1.80285 & 0.81554 & 0.11124 & $* *(\mathrm{~b}<1)$ & 0.6656 \\
Muscle & -0.80669 & 0.81003 & 0.07474 & $* *(\mathrm{~b}<1)$ & 0.8131 \\
Fat & -1.11175 & 1.60603 & 0.14878 & $* *(\mathrm{~b}>1)$ & 0.8119 \\
Others & -2.40155 & 1.45168 & 0.36273 & $* *(\mathrm{~b}>1)$ & 0.3723 \\
Shoulder & & & & \\
Bone & -1.55187 & 0.54031 & 0.06778 & $* *(\mathrm{~b}<1)$ & 0.7018 \\
Muscle & -0.52217 & 0.89364 & 0.05963 & $* *(\mathrm{~b}<1)$ & 0.8927 \\
Fat & -1.96128 & 1.67634 & 0.17582 & $* *(\mathrm{~b}>1)$ & 0.7710 \\
Others & -3.00177 & 1.45027 & 0.33085 & $* *(\mathrm{~b}>1)$ & 0.4158 \\
Rib & & & & \\
Bone & -1.38049 & 0.37337 & 0.12805 & $* *(\mathrm{~b}<1)$ & 0.2395 \\
Muscle & -0.52999 & 0.84629 & 0.05520 & $* *(\mathrm{~b}<1)$ & 0.8970 \\
Fat & -2.07241 & 1.73198 & 0.17826 & $* *(\mathrm{~b}>1)$ & 0.7776 \\
Others & -2.79685 & 1.34804 & 0.38067 & $* *(\mathrm{~b}>1)$ & 0.3172 \\
Leg & & & & \\
Bone & -1.47926 & 0.70400 & 0.04389 & $* *(\mathrm{~b}<1)$ & 0.9050 \\
Muscle & -0.43022 & 0.97531 & 0.03324 & $* *(\mathrm{~b}<1)$ & 0.9696 \\
Fat & -2.48235 & 1.46517 & 0.14688 & $* *(\mathrm{~b}>1)$ & 0.7866 \\
Others & -3.05740 & 1.22443 & 0.24307 & $* *(\mathrm{~b}>1)$ & 0.4845 \\
\hline
\end{tabular}

** Significant at $1 \%$ probability level; $\mathrm{ns}=$ not significant $(\mathrm{P}>0.05) ; \mathrm{Sb}=$ standard error of the regression coefficient; $\mathrm{R}^{2}=$ coefficient of determination.

Therefore, the results of the present study corroborate those obtained by Rosa et al. (2002), who evaluated Texel ram and ewe lambs under different feeding methods and reported that, in uncastrated lambs, muscle growth in the shoulder was relatively more accelerated, and thus considered of early growth.

Galvani et al. (2008) evaluated feedlot-finished Texel $\times$ Ile de France lambs slaughtered with different weights and observed that, irrespective of the cut, fat showed late growth $(b>1)$, whereas the bone growth was early $(b<1)$.

Similarly to the results found in this experiment,
Santos et al. (2001) studied the allometry of tissues in feedlot Santa Inês lambs slaughtered at 15, 25, 35 , and $45 \mathrm{~kg} \mathrm{LW}$, and observed early bone growth and late fat growth in relation to all cuts made in the carcass. The muscle tissue, in turn, had a relatively late growth in the leg, with $b=1.039$, unlike what occurred in the present study, in which this tissue, in relation to the leg, was early, with $b=0.97531$. These authors also concluded that the adequate slaughter weight range to meet the demands of the consumer market with respect to fat deposition are between 15 and $35 \mathrm{~kg} \mathrm{LW}$, because this tissue shows a positive heterogonic behavior, and is thus of late deposition, increasing with the increase in slaughter weight. 
The weights in $\mathrm{kg}$ of bone, muscle, and fat in the half-carcass increased as the LWS of the lambs increased (Table 4). Mean values were close to those obtained by Silva et al. (2000) in Texel $\times$ Ideal lambs also confined and slaughtered with different weights
$(20.9 \mathrm{~kg}, 28.3 \mathrm{~kg}$, and $32.6 \mathrm{~kg} \mathrm{LW})$. According to Osório et al. (2002), when the carcass weight is increased, the weights of bone, muscle, and fat increase, and consequently so does the weight of the carcass regions or commercial cuts.

Table 4. Mean values for the weight $(\mathrm{kg})$ and proportions (\%) of bone, muscle, fat, and other tissues relative to the right half-carcass, according to the live weight of lambs at slaughter.

\begin{tabular}{lcccccccc}
\hline & \multicolumn{9}{c}{ Treatment } & & & RV (\%) & P>F \\
\cline { 2 - 6 } Variable & $\mathbf{2 3}$ & $\mathbf{2 5}$ & $\mathbf{3 0}$ & $\mathbf{3 5}$ & $\mathbf{4 0}$ & $\mathbf{R E}$ & $\mathbf{C V}$ \\
Bone (kg) & 1.002 & 1.064 & 1.052 & 1.203 & 1.398 & 1 & 9.55 & 0.0001 \\
Muscle (kg) & 3.201 & 3.262 & 3.625 & 4.438 & 5.157 & 2 & 10.82 & 0.0001 \\
Fat (kg) & 0.848 & 0.934 & 1.292 & 1.606 & 2.103 & 3 & 15.36 & 0.0001 \\
Others (kg) & 0.316 & 0.352 & 0.538 & 0.651 & 0.638 & 4 & 20.41 & 0.0001 \\
Bone (\%) & 18.73 & 19.01 & 16.18 & 15.25 & 15.04 & 5 & 9.26 & 0.0002 \\
Muscle (\%) & 59.87 & 58.07 & 55.61 & 56.14 & 55.32 & $\bar{Y}=56.38$ & 4.86 & 0.1369 \\
Fat (\%) & 15.56 & 16.57 & 19.90 & 20.34 & 22.77 & 6 & 15.55 & 0.0037 \\
Others (\%) & 5.84 & 6.35 & 8.30 & 8.26 & 6.87 & 7 & 21.23 & 0.0180 \\
\hline
\end{tabular}

$1-\hat{Y}=0.44669+0.02248$ LWS. $R^{2}=0.58 ; 2-\hat{Y}=-0.04797+0.12849$ LWS. $R^{2}=0.74 ; 3-\hat{Y}=-0.98957+0.07600$ LWS. $R^{2}=0.80$; $4-\hat{Y}=-0.09933+0.01992$ LWS. $R^{2}=0.52 ; 5-\hat{Y}=24.87365-0.26273$ LWS. $R^{2}=0.51 ; 6-\hat{Y}=7.31023+0.38532$ LWS. $R^{2}=0.35$; $7-\hat{Y}=-29.41524+2.31153 \mathrm{LWS}-0.03515 \mathrm{LWS}^{2} . \mathrm{R}^{2}=0.27$; LWS: lamb weight at slaughter.

The proportions of bone and fat tissues increased linearly, while the proportion of muscle was not affected by the slaughter weight of the lambs. These results corroborate the assertion of Osório et al. (2000, 2002), that, considering the same breed, when the carcass weight is increased, the proportion of bone is reduced and fat increases, while the muscle tissue remains constant; i.e., the carcass gets proportionally fatter. In this regard, according to Silva et al. (2000), at birth, the animal displays a high proportion of bones that decreases as a function of the increased fat tissue deposition resulting from the advance of maturity.

In the present study, in T30 animals, the mean values of the proportions of tissues in the halfcarcass were $16.18 \%$ bone, $56.38 \%$ muscle, and $19.90 \%$ fat, while Pires et al. (1999) obtained bone, muscle, and fat percentages of $22.04 \%, 62.70 \%$, and $16.40 \%$, respectively, in feedlot-finished uncastrated lambs born from Texel rams and Texel $\times$ Ideal ewes, slaughtered at 100 days of age with an average live weight of $27.9 \mathrm{~kg}$. However, all proportions agree with those obtained by Bueno et al. (2000), who evaluated Suffolk lambs slaughtered at different ages and also found a decrease in the percentage of bone, an increase in the proportion of fat, and no variations in the muscle.

Therefore, as occurred with the cuts, the allometric growth of the tissues from the halfcarcass of the lambs was considered early $(b<1)$ for bone and muscle, and late $(b>1)$ for the fat (Table 5). Results were similar to those obtained by Galvani et al. (2008), whose values indicated that the increased carcass weight implied a reduction of the growth rate of bones and muscles $(b<1)$ and an increase in the fat growth rate $(b>1)$, which may impair the sale of the carcass of animals slaughtered with heavier weights. Thus, excess fat is a limiting factor in the production of heavier lambs, requiring the identification of breeds and crosses capable of generating more desirable carcasses, especially when animals are fed so as to achieve elevated weights.

Rosa et al. (2005), working with Texel lambs, and Santos et al. (2001), with Santa Inês and Bergamasca lambs, also reported early bone growth and late growth of the fat tissue. However, 
they reported similar muscle tissue growth to that of carcass. These divergences may, however, be related to the composition and tissue growth in the different regions of the carcass. Additionally, Silva et al. (2000) found that the muscle growth of lambs born from Texel rams with Texel $\times$ Ideal ewes is isometric in relation to the carcass and its cuts, indicating that on the average age range of 105 days of age, weights above $33 \mathrm{~kg}$ (packing-plant weight) may not be the most adequate, since high percentages of muscle and good fat deposition in the carcass are obtained up to this weight.

Table 5. Estimated parameters of the allometric equation of tissue components relative to the right half-carcass.

\begin{tabular}{lccccc}
\hline \multicolumn{1}{c}{ Variable } & A & B & Sb & $\begin{array}{c}\text { T test } \\
\text { Ho: } \mathbf{b}=\mathbf{1}\end{array}$ & $\mathbf{R}^{\mathbf{2}}$ \\
\hline Bone $(\mathrm{kg})$ & -0.94105 & 0.55613 & 0.06682 & $* *(\mathrm{~b}<1)$ & 0.7196 \\
Muscle $(\mathrm{kg})$ & -0.37219 & 0.89984 & 0.04598 & $* *(\mathrm{~b}<1)$ & 0.9341 \\
Fat $(\mathrm{kg})$ & -2.92347 & 1.64855 & 0.15889 & $* *(\mathrm{~b}>1)$ & 0.7995 \\
Others $(\mathrm{kg})$ & -3.34822 & 1.35091 & 0.27123 & $* *(\mathrm{~b}>1)$ & 0.4788 \\
\hline
\end{tabular}

** Significant at $1 \%$ probability level; $\mathrm{ns}=$ not significant $(\mathrm{P}>0.05) ; \mathrm{Sb}=$ standard error of the regression coefficient; $\mathrm{R}^{2}=$ coefficient of determination.

The allometric coefficients of bone, muscle, and fat in the shoulder (Table 3) are very close to those obtained in the different tissues of the animal carcass (Table 5), suggesting that the tissue growth pattern of this cut can be representative of the allometric growth of the different carcass tissues.
After the dissection of all tissues in the halfcarcass and regression analysis of the ratios among them, we observed that the muscle/fat ratio decreased in all cuts, and consequently, in the halfcarcass with the increase in lambs' LWS (Table 6). The muscle/bone, ratio, however, increased in the shoulder, rib, leg, and half-carcass, and there was no significant effect on the neck $(\overline{\mathrm{Y}}=2.80)$.

Table 6. Mean values for muscle/bone and muscle/fat ratios in the different cuts of lamb carcasses.

\begin{tabular}{|c|c|c|c|c|c|c|c|c|}
\hline \multirow[b]{2}{*}{ Variable } & \multicolumn{5}{|c|}{ Treatment } & \multirow[b]{2}{*}{$\mathbf{R E}$} & \multirow[b]{2}{*}{ CV $(\%)$} & \multirow[b]{2}{*}{$\mathbf{P}>\mathbf{F}$} \\
\hline & 23 & 25 & 30 & 35 & 40 & & & \\
\hline \multicolumn{9}{|l|}{ Neck } \\
\hline Muscle/bone & 2.68 & 2.73 & 2.85 & 2.60 & 3.08 & $\overline{\mathrm{Y}}=2.80$ & 23.36 & 0.5761 \\
\hline Muscle/fat & 3.50 & 2.88 & 1.88 & 2.12 & 1.84 & 1 & 26.38 & 0.0141 \\
\hline \multicolumn{9}{|l|}{ Shoulder } \\
\hline Muscle/bone & 3.15 & 2.83 & 3.15 & 3.48 & 3.44 & 2 & 10.93 & 0.0033 \\
\hline Muscle/fat & 4.12 & 3.90 & 3.18 & 2.87 & 2.56 & 3 & 25.66 & 0.0096 \\
\hline \multicolumn{9}{|l|}{ Rib } \\
\hline Muscle/bone & 2.95 & 2.98 & 3.62 & 4.15 & 3.70 & 4 & 13.78 & 0.0064 \\
\hline Muscle/fat & 3.42 & 2.67 & 1.93 & 1.92 & 1.80 & 5 & 25.37 & 0.0147 \\
\hline \multicolumn{9}{|l|}{ Leg } \\
\hline Muscle/bone & 8.95 & 3.37 & 3.63 & 3.73 & 3.92 & 6 & 7.36 & 0.0024 \\
\hline Muscle/fat & 5.85 & 5.82 & 5.13 & 4.85 & 4.30 & 7 & 19.40 & 0.0171 \\
\hline \multicolumn{9}{|l|}{ Half carcass } \\
\hline Muscle/bone & 3.18 & 3.03 & 3.42 & 3.68 & 3.68 & 8 & 9.04 & 0.0010 \\
\hline Muscle/fat & 4.22 & 3.68 & 2.93 & 2.82 & 2.54 & 9 & 21.70 & 0.0088 \\
\hline
\end{tabular}


The fat of all cuts grows late, whereas muscle growth occurs early, indicating that the highest muscle/fat ratio will be obtained in the carcass (regardless of the cut) of younger animals, i.e., those slaughtered with lower weights.

The muscle/bone ratio of the carcass of animals from T30 was similar to that found by Silva and Pires (2000), who also found a ratio of 3.42:1 in lambs born from Texel rams and Texel $\times$ Ideal ewes in the feedlot and slaughtered at $32.57 \mathrm{~kg}$ live weight.

In comparison with the results obtained by Mendonça et al. (2008), who evaluated Texel lambs born in August, kept with their mother on a native field and slaughtered on average at 129 days of age, we can state that, in the present study, the muscle/ bone ratio in the shoulder and leg was higher in the animals from all treatments, whereas the muscle/fat ratio was only higher in T23 and T25. The lower muscle/fat ratio in the animals of the majority of the treatments in the current study, compared with the experiment of Mendonça et al. (2008), was likely due to the difference in the type of diet supplied to the animals, since animals finished in a complete feedlot system naturally deposit more fat in the carcass as a result of the presence of the concentrate, and hence the higher energy level of the diet.

The muscle/bone ratios of the leg of the animals from all treatments, except $\mathrm{T} 23$, were similar to the average 3.64 obtained by Moreno et al. (2010), who evaluated diets with different proportions of roughage and concentrate in feedlot Ile de France lambs slaughtered with an average weight of $31.6 \mathrm{~kg}$. The muscle/fat ratio found in the present experiment, however, was higher than the average 4.08 observed by these researchers. However, this ratio in the leg of animals from T23, T25, and T30 was close to the 5.71 found by Fernandes et al. (2010) in feedlot-finished Suffolk lams slaughtered with $32 \mathrm{~kg}$ LW.

\section{Conclusions}

Bone and muscle tissues show early growth, whereas the fat has late growth in the different commercial cuts and in the carcass of Texel lambs. Furthermore, the proportion of bone decreases and that of fat increases in the carcass of Texel lambs as they grow. The tissue growth pattern of the shoulder can be representative of the allometric growth of the different carcass tissues. The increase in slaughter weight of Texel lambs leads to a reduction of the muscle/fat ratio as a consequence of the greater fat deposition in the carcass of these animals.

\section{References}

BLACK, J. L. Sheep production. Growth and development of lambs. London: Butterworths, 1983. 576 p.

BUENO, M. S.; CUNHA, E. A.; SANTOS, L. E.; RODA, D. S.; LEINZ, F. F. Características de carcaça de cordeiros Suffolk abatidos em diferentes idades. Revista Brasileira de Zootecnia, Viçosa, MG, v. 29, n. 6, p. 18031810, 2000.

CARVALHO, S.; VERGUEIRO, A.; KIELING, R.; TEIXEIRA, R. C.; PIVATO, J.; VIERO, R.; CRUZ, A. N. da. Desempenho e características da carcaça de cordeiros das raças Texel, Suffolk e cruza Texel x Suffolk. Ciência Rural, Santa Maria, v. 35, n. 5, p. 1155-1160, 2005.

DIAZ, M. T.; VELASCO, S.; CAÑEQUE, V.; LAUZURICA, S.; RUIZ de HUIDOBRO, F.; PÉREZ, C.; GONZÁlEZ, J.; MANZANARES, C. Use of concentrate or pasture for fattening lambs and its effect on carcass and meat quality. Small Ruminant Research, Amsterdam, v. 43, n. 3, p. 257-268, 2002.

FERNANDES, M. A. M.; MONTEIRO, A. L. G.; POLI, C. H. E. C.; BARROS, C. S.; ALMEIDA, R.; RIBEIRO, T. M. D. Composição tecidual da carcaça e perfil de ácidos graxos da carne de cordeiros terminados a pasto ou em confinamento. Revista Brasileira de Zootecnia, Viçosa, MG, v. 39, n. 7, p. 1600-1609, 2010.

GALVANI, D. B.; PIRES, C. C.; OLIVEIRA, F.; WOMMER, T. P.; JOCHIMS, F. Crescimento alométrico dos componentes da carcaça de cordeiros Texel x Ile de France confinados do desmame aos $35 \mathrm{~kg}$ de peso vivo. Ciência Rural, Santa Maria, v. 38, n. 9, p. 2574-2578, 2008. 
HUXLEY, J. S. Problems of relative growth. Londres: Methuen, 1932. $276 \mathrm{p}$.

MENDONÇA, G.; OSÓRIO, J. C. S.; OSÓRIO, M. T. M.; SILVEIRA, I. D. B.; GONÇALVES, M.; ROCHA, A. Época de nascimento sobre a composição regional e tecidual da carcaça de cordeiros da raça Texel. Revista Brasileira de Zootecnia, Viçosa, MG, v. 37, n. 6, p. 1072 1078, 2008.

MORENO, G. M. B.; SILVA SOBRINHO, A. G.; LEÃO, A. G.; LOUREIRO, C. M. B.; PEREZ, H. I. Rendimentos de carcaça, composição tecidual e musculosidade da perna de cordeiros alimentados com silagem de milho ou cana-de-açúcar em dois níveis de concentrado. Arquivo Brasileiro de Medicina Veterinária e Zootecnia, Belo Horizonte, v. 62, n. 3, p. 686-695, 2010.

NATIONAL RESEARCH COUNCIL - NRC. Nutrient requirements of small ruminants: sheep, goats, cervids, and new world camelids. Washington, D.C: National Academy Press, 2007. 408 p.

OLIVEIRA, N. M.; OSÓRIO, J. C. S.; MONTEIRO, E. M. Produção de carne em ovinos de cinco genótipos. 4. Composição regional e tecidual. Ciência Rural, Santa Maria, v. 28, n. 1, p. 125-129, 1998.

OSÓRIO, J. C.; OLIVEIRA, N. M.; OSÓRIO, M. T.; PIMENTEL, M.; POUEY, J. L. Efecto de la edad al sacrificio sobre la producción de carne en corderos no castrados de cuatro razas. Revista Brasileira de Agrociência, Pelotas, v. 6, n. 2, p. 161-166, 2000.

OSÓRIO, J. C. S.; OSÓRIO, M. T. M.; JARDIM, P. O.; POUEY, L. O.; LÜDER, W. E.; CARDELLINO, R. A.; OLIVEIRA, N. M.; GULARTE, M. A.; BORBA, M. F.; MOTTA, L.; ESTEVES, R.; MONTEIRO, E.; ZAMBIAZI, R. Métodos para avaliação da produção de carne ovina, in vivo, na carcaça e na carne. Pelotas: Editora Universitária, 1998. 107 p.

OSÓRIO, J. C. S.; OSÓRIO, M. T.; OLIVEIRA, N. M.; SIEWERDT, L. Qualidade, morfologia e avaliação de carcaças. Pelotas: Editora e Gráfica Universitária, 2002. $196 \mathrm{p}$.
PIRES, C. C.; CARVALHO, S.; GRANDI, A.; KLESZTA, R.; FALLEIRO, V. Características quantitativas e composição tecidual da carcaça de cordeiros terminados em confinamento. Ciência Rural, Santa Maria, v. 29, n. 3, p. 539-543, 1999.

ROSA, G. T.; PIRES, C. C.; SILVA, J. H. S.; MOTTA, O. S. Crescimento alométrico de osso, músculo e gordura em cortes da carcaça de cordeiros Texel segundo os métodos de alimentação e peso de abate. Ciência Rural, Santa Maria, v. 35, n. 4, p. 870-876, 2005.

ROSA, G. T.; PIRES, C. C.; SILVA, J. H. S.; MÜLLER, L. Crescimento de osso, músculo e gordura dos cortes da carcaça de cordeiros e cordeiras em diferentes métodos de alimentação. Revista Brasileira de Zootecnia, Viçosa, MG, v. 31, n. 6, p. 2283-2289, 2002.

SANTOS, C. L.; PÉRES, J. R. O.; MUNIZ, J. A.; GERASEEV, L. C.; SIQUEIRA, E. R. Desenvolvimento relativo dos tecidos ósseo, muscular e adiposo dos cortes da carcaça de cordeiros Santa Inês. Revista Brasileira de Zootecnia, Viçosa, MG, v. 30, n. 2, p. 487-492, 2001.

SANTOS-SILVA, J.; MENDES, I. A.; BESSA, R. J. B. Effect of genotype, feeding system and sloughter weight on the quality of light lambs. I. Growth, carcass composition and meat quality. Livestock Production Science, Elsevier, v. 76, n. 1, p. 17-25, 2002.

SAÑUDO, C.; SIERRA, I. Calidad de la canal y de la carne en la especie ovina. Ovino y caprino. Madrid: Consejo General de Colegios Veterinarios de España, 1993. $337 \mathrm{p}$.

SILVA, L. F.; PIRES, C. C. Avaliações quantitativas das proporções de osso, músculo e gordura da carcaça em ovinos. Revista Brasileira de Zootecnia, Viçosa, MG, v. 29, n. 4, p. 1253-1260, 2000.

SILVA, L. F.; PIRES, C. C.; SILVA, J. H. S.; MEIER, D. O.; RODRIGUES, G. C.; CARNEIRO, R. M. Crescimento de cordeiros abatidos com diferentes pesos. Osso, músculo e gordura da carcaça e de seus cortes. Ciência Rural, Santa Maria, v. 30, n. 4, p. 671-675, 2000.

STATISTICAL ANALYSIS SYSTEM - SAS. Statistical analysis system user's guide: statistics. Version 8.2, Cary: SAS Institute, 2001. 1686 p. 